\title{
PERMAINAN INTERAKTIF UNTUK MENUMBUHKAN PARTISIPASI AKTIF, DAN KEMAMPUAN KOMUNIKASI MATEMATIS MAHASISWA MELALUI PENERAPAN LESSON STUDY
}

\author{
Wanda Nugroho Yanuarto \\ Pendidikan Matematika, Fakultas Keguruan dan Ilmu Pendidikan, \\ Universitas Muhammadiyah Purwokerto \\ wandanugroho86@gmail.com
}

\begin{abstract}
Abstrak
Tujuan dari penelitian ini adalab untuk mendeskripsikan bagaimana permainan interaktif dapat diaplikasikan pada mata kuliah geometri analitik bidang melalui penerapan lesson study. Penelitian ini terdiri dari 4 siklus, setiap siklus terdari dari 3 tabap yaitu plan, do, see. Subjek penelitian ini adalab mabasiswa semester I kelas A angkatan 2014 pendidikan matematika Universitas Mubammadiyab Purwokerto. Data penelitian ini yaitu melalui lembar observasi, rekaman video, portofolio, dan angket. Data dianalisis melalui reduksi data, penyajian data, dan penarikan kesimpulan. Hasil penelitian ini menunjukkan bahwa partisipasi aktif, dan kemampuan komunikasi matematis mahasiswa dan inovasi pembelajaran dapat tumbub melalui penerapan lesson study.
\end{abstract}

\section{Kata kunci: permainan interaktif, partisipasi aktif, kemampuan komunikasi matematis, lesson study}

\begin{abstract}
The purpose of this study was to describe how interactive games can be applied in the field of analytic geometry courses through the implementation of lesson study. The study consisted of four cycles, each cycle shall be composed of three stages: plan, do, see. The subjects were students of the first semester 2014 class A class of math education Universitas Muhammadiyah Purwokerto. This research data is through observation sheets, video recordings, portfolios, and questionnaires. The data were analyzed through data reduction, data presentation, and conclusion. The results of this study indicate that the active participation, and student mathematical communication skills and learning innovations can grow through the implementation of lesson study.
\end{abstract}

Keywords: interactive games, active-participation, math-conection ability, lesson study

\section{PENDAHULUAN}

Belajar adalah proses perubahan tingkah laku yang berupa pengetahuan, sikap, dan keterampilan. Perubahan ini bersifat menetap dalam tingkah laku yang terjadi sebagai suatu hasil latihan atau pengalaman. Proses belajar bersifat individual artinya sesuatu yang dilakukan oleh mahasiswa bukan dibuat oleh mahasiswa. Pembelajaran pada hakekatnya adalah suatu proses interaksi antara mahasiswa dengan lingkungannya baik antar mahasiswa dengan mahasiswa, mahasiswa dengan sumber belajar, maupun mahasiswa dengan pendidik. Kegiatan pembelajaran ini akan menjadi bermakna bagi mahasiswa jika dilakukan dalam lingkungan yang nyaman dan memberikan rasa aman bagi mahasiswa. Pembelajaran pada dasarnya merupakan upaya pendidik untuk membantu mahasiswa dalam melaksanakan kegiatan belajar, demi mencapai hasil belajar yang memuaskan (Isjoni, 2009).

Ausubel (1963) menyatakan bahwa bahan pelajaran yang dipelajari harus "bermakna" (meaningful). Pembelajaran bermakna merupakan suatu proses mengaitkan informasi baru pada konsep-konsep relevan yang terdapat dalam struktur kognitif seseorang. Struktur kognitif ialah fakta-fakta, konsep-konsep, dan generalisasi- 
generalisasi yang telah dipelajari dan diingat mahasiswa. Belajar bermakna menurut Ausubel (1963) merupakan proses mengaitkan informasi atau materi baru dengan konsep-konsep yang telah ada dalam struktur kognitif. Ada tiga faktor yang mempengaruhi kebermaknaan dalam suatu pembelajaran, yaitu struktur kognitif yang ada, stabilitas dan kejelasan pengetahuan dalam suatu bidang studi tertentu, dan pada waktu tertentu.

Suparno (1997) mengatakan, bahwa pembelajaran bermakna adalah sutu proses pembelajaran dimana informasi baru dihubungkan dengan struktur pengertian yang sudah dipunyai seorang yang sedang dalam proses pembelajaran. Pembelajaran bermakna adalah pembelajaran yang menyenangkan yang akan memiliki keunggulan dalam meraup segenap informasi secara utuh sehingga konsekuensi akhir meningkatkan kemampuan mahasiswa. Dengan demikian, agar terjadi belajar bermakna maka dosen harus selalu berusaha mengetahui dan menggali konsep-konsep yang telah dimiliki mahasiswa dan membantu memadukannya secara harmonis konsep-konsep tersebut dengan pengetahuan baru yang akan diajarkan.

Matematika merupakan salah satu bidang studi yang diajarkan di setiap jenjang pendidikan. Banyak permasalahan dan kegiatan dalam hidup yang harus diselesaikan dengan menggunakan ilmu matematika seperti menghitung mengukur, dan lainnya. Oleh karena itu, matematika sebagai salah satu ilmu dasar memiliki peranan penting dalam mencerdaskan mahasiswa karena dapat menumbuhkan kemampuan penalaran yang sangat dibutuhkan dalam perkembangan ilmu dan teknologi. Dalam belajar matematika dibagi atas beberapa bidang, diantaranya adalah belajar geometri. Peranan geometri dalam matematika sangat kuat, bukan saja geometri hanya membina proses berpikir akan tetapi juga sangat mempengaruhi bidang matematika yang lain.

Untuk menyelesaikan masalah dalam geometri, maka mahasiswa harus terlebih dahulu memahami konsep atau sifat-sifat dari geometri sehingga mudah dipahami dan tidak terjadi kesalahan. Dengan melihat kedudukan matematika dalam perkembangan pengetahuan dan tekonologi, maka terdapat banyak cara yang digunakan untuk meningkatkan kualitas pendidikan matematika. Dalam kegiatan belajar mengajar pendidik harus memiliki strategi agar mahasiswa dapat belajar secara efektif dan efisien, sehingga diharapkan dapat menguasai konsep-konsep dan aturan-aturan dari materi serta mampu menghubungkan materi yang baru diterimanya dengan apa yang telah dipelajarinya. Agar konsep-konsep geometri dapat dipahami dengan benar, maka perlu mengetahui tahaptahap pemahaman dalam geometri menurut Van Hiele.

Namun dalam perkuliahan, khususnya bagi para mahasiswa baru semester I perlu dikenalkan partisipasi aktif, dan bagaimana mahasiswa dapat mengkomunikasikan pendapat, gagasan, serta ide selama perkuliahan. Sehingga pada kegiatan lesson study kali ini penulis menganggap bahwa bagaimana proses pembelajaran diinovasi dengan baik melalui permainan (games) dan melihat partisipasi aktif, dan kemampuan komunikasi matematis mahasiswa.

Pelaksanaan pembelajaran partisipasi aktif perlu memperhatikan beberapa prinsip sebagai berikut. Pertama, berdasarkan kebutuhan belajar (learning needs based) sebagai keinginan maupun kehendak yang dirasakan oleh mahasiswa. Kedua, berorientasi kepada tujuan kegiatan belajar (learning goals and objectives oriented). Prinsip ini mengandung arti bahwa pelaksanaan pembelajaran partisipasi aktif berorientasi kepada usaha pencapaian tujuan yang telah ditetapkan.

Ketiga, berpusat kepada mahasiswa (participant centered). Prinsip ini sering disebut learning centered, yang menunjukkan bahwa kegiatan belajar selalu bertolak dari kondisi nyata kehidupan mahasiswa. Keempat, belajar berdasarkan pengalaman (experiental learning), bahwa kegiatan belajar harus selalu dihubungkan dengan pengalaman mahasiswa. Dari pendapat partisipasi aktif oleh Suryosubroto, dijabarkan kedalam beberapa indikator, yaitu:

1. Mahasiswa harus terlibat dalam proses belajar

a. Turut aktif dalam proses pembelajaran

b. Mengikuti pelajaran dengan baik

2. Berlatih untuk menjelajah, mencari, dan mempertanyakan sesuatu 
a. Mengerjakan tugas baik terstruktur maupun maupun tanpa terstruktur di kelas dan di rumah dengan baik

b. Mengambil keterangan atau informasi dari buku

c. Berinisiatif mempelajari dan mengerjakan materi pelajaran yang belum dan akan diajarkan

d. Menyampaikan pertanyaan

3. Menyelidiki jawaban atas pertanyaan

a. Menyampaikan pendapat, ide, atau sanggahan

b. Mencari jalan memecahkan masalah

4. Mengelola dan menyampaikan hasil perolehannya secara komunikatif

a. Membuat catatan ringkas

b. Menyampaikan jawaban hasil diskusi kelompok maupun mandiri

Pembelajaran yang menitikberatkan kepada partisipasi aktif mahasiswa, pendidik berperan sebagai fasilitator, bertugas membantu memudahkan mahasiswa belajar, sebagai narasumber yang harus mampu mengundang pemikiran dan daya kreasi mahasiswanya. Pendidik harus mampu merancang, melaksanakan kegiatan bermakna dan dapat mengelola sumber belajar yang diperlukan serta menggunakan model pembelajaran yang menuntut mahasiswa untuk ikut serta berpartisipasi aktif dalam proses pembelajaran.

Berdasarkan uraian di atas, dapat disimpulkan bahwa partisipasi aktif mahasiswa adalah keterlibatan atau keikutsertaan mahasiswa secara aktif dalam proses belajar mengajar atau perkuliahan baik pikiran maupun tenaga guna mengembangkan daya piker serta menyampaikan hasil pemikirannya secara komunikatif untuk mencapai kemanfaatan pembelajaran secara optimal. Indikator partisipasi aktif yang digunakan dalam penelitian ini adalah sebagai berikut:

1. Keterlibatan dalam proses belajar

a. Turut aktif dalam proses pembelajaran

b. Mengikuti pelajaran dengan baik

2. Berlatih mencari, dan mempertanyakan sesuatu

a. Mengerjakan tugas baik terstruktur maupun tanpa terstruktur di kelas dan di rumah dengan baik b. Berinisiatif mempelajari dan mengerjakan materi pelajaran yang belum dan akan dikerjakan

3. Menyelidiki jawaban atas pertanyaan

a. Menyampaikan pendapat, ide, atau sanggahan

b. Mencari jalan memecahkan masalah

Komunikasi matematis adalah cara untuk menyampaikan ide-ie pemecahan masalah, strategi maupun solusi matematika baik secara tertulis maupun lisan. Sedangkan kemampuan komunikasi matematis dalam pemecahan masalah menurut National Council of Teachers of Mathematics (2000) dapat dilihat ketika peserta didik menganalisis dan menilai pemikiran dan strategi matematis orang lain dan menggunakan bahasa matematika untuk menyatakan ide matematika dengan tepat. Selain itu, menurut Schoen, Bean, dan Zieberth (dalam Bistari, 2010) kemampuan memberikan dugaan tentang gambar-gambar geometri juga termasuk kemampuan komunikasi matematis.

Menurut Silver and Smith (1993), pembelajaran harus dapat membantu peserta didik mengkomunikasikan ide matematika melalui lima aspek komunikasi yaitu representing, listening, reading, discussing dan writing. Dengan demikian, kemampuan komunikasi matematis sebagai salah satu aktivitas sosial (talking) maupun sebagai alat bantu berpikir (writing).

Berdasarkan pengertian komunikasi matematis di atas, dapat dikatakan bahwa kemampuan komunikasi matematis merupakan kemampuan seseorang dalam mengkomunikasikan gagasan atau ide-ide matematika dengan simbol, tabel, diagram, atau media lain untuk memperjelas keadaan atau masalah serta mendiskusikannya dengan orang lain. Adapun indikator kemampuan komunikasi matematis lisan sebagai berikut:

1. Mengekspresikan ide-ide matematis melalui lisan, dan mendemonstrasikannya serta menggambarkannya secara visual.

2. Memahami, menginterpretasikan, dan mengevaluasi ide-ide matematis secara lisan.

3. Menggunakan istilah-istilah, notasi-notasi matematika dan struktur-strukturnya untuk menyajikan ide-ide menggambarkan hubunganhubungan dengan model-model situasi. 
Sedangkan indikator kemampuan komunikasi matematis tertulis sebagai berikut:

1. Mengekspresikan ide-ide matematis melalui tulisan, dan mendemonstrasikannya serta menggambarkannya secara visual

2. Memahami menginterpretasikan, dan mengevaluasi ide-ide matematis secara tertulis.

3. Menggunakan istilah-istilah, notasi-notasi matematika dan struktur-strukturnya untuk menyajikan ide-ide menggambarkan hubungan-hubungan dengan model-model situasi.

Dalam penelitian ini penulis ingin mengetahui deskripsi kemampuan matematis tertulis mahasiswa, karena pada hal ini kemampuan komunikasi matematis secara lisan sudah dapat terangkum dalam partisipasi aktif mahasiswa.

Lesson study merupakan sebuah pendekatan untuk meningkatkan kualitas pembelajaran yang awal mulanya berasal dari Jepang (Susilo, 2009). Syamsuri menjelaskan bahwa lesson study merupakan salah satu bentuk penerapan konsep komunitas belajar yang saling belajar satu sama lain untuk meningkatkan pengetahuannya. Kemendiknas (2012) mendefinisikan lesson study sebagai suatu metode analisis kasus pada praktek pembelajaran, ditujukan untuk membantu pengembangan profesional para pengajar dan membuka kesempatan bagi mereka untuk saling belajar berdasarkan praktek-praktek pembelajaran di kelas.

Lesson study memiliki tahapan-tahapan dalam siklusnya. Tahap pertama adalah plan dengan kegiatannya yaitu komunitas pengajar menyusun rencana pembelajaran atau merancang pembelajaran. Tahap kedua adalah do dengan kegiatannya yaitu melaksanakan pembelajaran yang dilakukan oleh salah seorang pengajar pengampu pelajaran dan mengamati pembelajaran yang dilakukan oleh pengajar-pengajar lain yang tergabung dalam komunitas pengajar yang melakukan lesson study. Tahap ketiga adalah see dengan kegiatannya yaitu komunitas pengajar merefleksi dari pembelajaran yang telah dilakukan dan hasil pengamatan selama pembelajaran untuk kemudian dijadikan bahan perencanaan pembelajaran selanjutnya.
Dalam penelitian kali ini, geometri menempati posisi khusus dalam kurikulum matematika karena banyak konsep-konsep yang termuat didalamnya. Dari sudut pandang psikologi, geometri merupakan penyajian abstraksi dari pengalaman visual dan spasial, misalnya bidang, pola, pengukuran, dan pemetaan. Sedangkan dari sudut pandang matematik, geometri menyediakan pendekatan-pendekatan untuk pemecahan masalah misalnya gambar-gambar, diagram, sistem koordinat, dan vektor.

Dari penjelasan di atas, dapat disimpulkan bahwa dalam pembelajaran Geometri Analitik Bidang yang diajarkan pada mahasiswa di kelas A semester 1 adalah pembelajaran yang disajikan secara bermakna yaitu mahasiswa dapat membuat skema konsep dalam pemikiran mereka dari setiap pertemuan yang ada. Proses pembelajaran yang dilakukan dengan menggunakan permainan agar proses penemuan konsep dapat dilakukan secara menyenangkan dan mudah diingat. Permainan yang dilakukan selama proses lesson study ini adalah Guess and Check, Paper Plane, Secret inside Baloon, dan Mistery Box.

\section{METODOLOGI}

Penelitian ini merupakan penelitian deskriptif kualitatif dengan tahapan pembelajaran berbasis lesson study. Penelitian dilakukan pada semester genap tahun akademik 2014/2015 di Universitas Muhammadiyah Purwokerto (UMP). Subyek dari penelitian ini adalah mahasiswa semester I kelas A program studi Pendidikan Matematika UMP yang menempuh mata kuliah Geometri Analitik Bidang semester gasal tahun akademik 2014/2015.

Pelaksanaan penelitian dilakukan sebanyak 4 siklus dengan tahapan setiap siklusnya yaitu sebagai berikut.

\section{Plan (Perencanaan)}

Tahap ini, dosen model bersama lima dosen observer melakukan perencanaan pembelajaran. Pelaksanaan tahap ini yaitu dosen model memberikan perangkat pembelajaran kepada dosen observer yang selanjutnya dilakukan evaluasi atas perangkat yang direncanakan tersebut. Perangkat pembelajaran tersebut terdiri dari 
satuan acara perkuliahan, denah tempat duduk, lembar observasi pembelajaran, dan lembar observasi paritisipasi aktif dan kemandirian belajar. Pembelajaran yang dilaksanakan yaitu pembelajaran yang berpusat pada mahasiswa dengan tujuan meningkatkan paritisipasi aktif, dan kemandirian belajar mahasiswa.

\section{Do (Pelaksanaan)}

Pada tahap ini, dosen model mempraktekkan pembelajaran sesuai dengan hasil kesepakatan pada tahap plan. Pegangan aktivitas dosen model dan aktivitas mahasiswa dalam pembelajaran yaitu berdasarkan SAP yang telah disepakati bersama pada tahap plan. Peran observer pada tahap ini adalah mencatat aktivitas mahasiswa yang membutuhkan perhatian dan mencatat perkembangan partisipasi aktif, dan kemandirian belajar mahasiswa. Panduan dosen observer dalam melakukan observasi adalah denah tempat duduk mahasiswa, SAP, lembar observasi pembelajaran, dan lembar observasi partisipasi aktif, dan kemandirian belajar mahasiswa. Panduan dosen observer ini yaitu sesuai dengan kesepakatan yang telah terbentuk pada tahap plan

\section{See (Refleksi dan Evaluasi)}

Tujuan tahap ini adalah untuk melakukan refleksi dan evaluasi dari pelaksanaan pembelajaran pada tahap do. Pelaksanaan tahap ini diawali dengan pemaparan dari dosen model atas pelaksanaan pembelajaran yang telah dilakukan. Dosen model memberikan refleksi diri atas apa yang dirasakan dan apa yang terjadi selama pelaksanaan pembelajaran berlangsung. Dosen model juga dapat mengungkapkan kesulitan-kesulitan yang dialami selama pelaksanaan pembelajaran. Kegiatan pada tahap ini dilanjutkan dengan pemaparan oleh dosen observer atas temuantemuan yang diperoleh selama pelaksanaan tahap do. Temuan tersebut yaitu dapat berupa temuan positif maupun temuan negatif terhadap pelaksanaan pembelajaran dan partisipasi aktif, dan kemandirian belajar mahasiswa. Kegiatan selanjutnya pada tahap ini yaitu pemberian masukan dari dosen observer atas permasalahan yang terjadi. Hasil masukan ini kemudian dituangkan dalam bentuk SAP oleh dosen model yang selanjutnya sebagai bahan pembahasan pada tahap plan untuk siklus berikutnya.

Pengumpulan data dari penelitian ini dilakukan dengan cara:

\section{Observasi}

Observasi dilakukan pada saat proses pembelajaran berlangsung yaitu pada tahap do. Pelaksanaan observasi dilakukan oleh lima dosen observer. Lembar observasi yang digunakan terdiri dari lembar observasi kegiatan pembelajaran dan lembar observasi partisipasi aktif dan kemandirian belajar. Lembar observasi tersebut berupa pertanyaan-pertanyaan tentang pelaksanaan pembelajaran, partisipasi aktif dan kemandirian belajar mahasiswa, dan temuan yang diperoleh observer selama proses pembelajaran

\section{Angket}

Angket diberikan kepada mahasiswa dengan tujuan untuk mengetahui partisipasi aktif dan kemandirian belajar mahasiswa setelah pelaksanaan pembelajaran berlangsung. Angket yang digunakan yaitu berupa pernyataanpernyataan tertutup untuk menggambarkan partisipasi aktif dan kemandirian belajar pada mahasiswa. Pengisian angket dilakukan dengan memberi tanda cek pada kolom yang sesuai dengan kondisi mahasiswa. Kolom tersebut yaitu berisi skor 1 yang berarti tidak pernah, skor 2 yang berarti jarang, skor 3 yang berarti sering, dan skor 4 yang berarti selalu

\section{Dokumentasi}

Dokumen yang digunakan berupa rekaman video, foto dan portofolio mahasiswa dari setiap pelaksanaan plan, do, dan see.

Data yang telah diperoleh kemudian dianalisis secara kualitatif yaitu melalui reduksi data, penyajian data, dan penarikan kesimpulan. Reduksi data difokuskan pada kegiatan mahasiswa yang berkaitan dengan motivasi belajar dan temuan-temuan baru yang menarik dalam pembelajaran. Dari hasil reduksi data kemuian dilakukan penyajian data dalam bentuk gambar ataupun uraian penjelasan. Analisis selanjutnya yaitu dilakukan penarikan kesimpulan dengan 
memperhatikan dan menggabungkan dari berbagai data yang diperoleh.

\section{HASIL DAN PEMBAHASAN}

Hasil dan temuan-temuan selama pelaksanaan lesson study dirangkum berdasarkan tiap tahapan pada tiap siklus dari pembelajaran yang dilakukan. Adapun secara rinci yaitu sebagai berikut.

\section{Siklus I}

Plan

Pembahasan utama pada tahap plan untuk siklus I ini yaitu tentang model pembelajaran yang akan digunakan pada tahap do. Model pembelajaran yang digunakan adalah pembelajaran kooperatif dengan termodifikasi permainan (games). Modifikasi tersebut yaitu pada teknik pelaksanaan diskusi dan proses pembelajaran. Pada saat pembelajaran mahasiswa diberi kebebasan dalam melaksanakan diskusi guna menemukan konsep materi yang sedang diajarkan pada hari itu. Mahasiswa melakukan diskusi menemukan konsep dengan dibantu lembar kerja mahasiswa (LKM). LKM tersebut berisi panduan kepada mahasiswa untuk menemukan konsep materi, hal ini bertujuan untuk mengarahkan mahasiswa agar proses berpikir mahasiswa sejalan dengan apa yang dikehendaki Dosen dalam menemukan konsepnya. Proses diskusi yang diarahkan tersebut juga dinilai bagaimana partisipasi aktif, dan kemampuan komunikasi matematis selama pelaksanaan pembelajaran. Modifikasi selanjutnya yaitu pada saat sebelum dilakukan pembelajaran dan setelah dilaksanakan pembelajaran, mahasiswa diberi kesempatan untuk mengilustrasikan perasaannya ke dalam selembar kertas emoticon, hal ini untuk menganalisa ketertarikan mahasiswa selama proses pembelajaran.

Di dalam proses diskusi, dilaksanakan sebuah permainan (games) yang didasarkan atas karakteristik geometri dipandang dari teori belajar Dienes, Van Hiele, dan strategi serta model pembelajaran yang ada. Berdasarkan hal tersebut, maka permainan (games) dipandang perlu untuk dilaksanakan dalam pembelajaran geometri analitik bidang. Pada pelaksanaan Do 1, permainan yang digunakan adalah permainan menebak dan mengecek penyelesaian masalah yang ada (guess and check), permainan ini didasarkan atas strategi pemecahan masalah (problem solving). Dalam 11 strategi pemecahan masalah (problem solving) terdapat sebuah strategi untuk memecahkan sebuah permasalahan yaitu guess and check, yaitu mahasiswa diminta untuk menebak dan mengecek hasil sebuah penyelesaian dari permasalahan yang sedang dihadapi.

Dosen memberikan empat permasalahan matematika dan dua alternative penyelesaian dari masing-masing permasalahan. Berdasarkan hal tersebut, mahasiswa diminta untuk mencari tahu mana penyelesaian masalah yang tepat. Proses ini dilaksanakan dalam diskusi kelompok, sehingga diharapkan dalam diskusi tersebut bisa dilihat partisipasi aktif mahasiswa.

Setelah proses permainan selesai, mahasiswa diminta untuk mempresentasi hasil diskusinya berupa penemuan sebuah konsep yang sudah didapatkan dan hasil permainan tersebut. Bahan presentasi yang dilakukan mahasiswa bersumber dari materi kelompok pasangannya, jadi mereka bukan mempresentasikan materinya sendiri. $\mathrm{Hal}$ ini bertujuan agar mahasiswa bisa berpartisipasi aktif dalam proses diskusi dalam mempelajari materi tersebut.

Do

Pelaksanaan pada tahap do telah sesuai dengan SAP yang dibentuk, hanya saja masih banyak mahasiswa yang membutuhkan pengarahan tentang teknik pembelajaran. Hal ini terjadi karena model pembelajaran ini terhitung baru bagi mahasiswa sehingga butuh penyesuaian. Pada pelaksanaan penempelan emoticon mahasiswa masih terlihat mengganggu mahasiswa lain dalam pembelajaran tersebut, sehingga proses penempelan emoticon membuat situasi belajar di kelas tidak kondusif.

Dalam proses diskusi, terlihat beberapa mahasiswa sudah berpartisipasi aktif dalam kelompoknya. Terlihat dalam kelompok I, mahasiswa yang bernama Retno Isworo Putri tampak berpartisipasi aktif dalam memimpin proses diskusi, akan tetapi ada juga mahasiswa yang nampaknya tidak antusias dalam proses diskusi di kelompoknya, sebagai contoh pada 


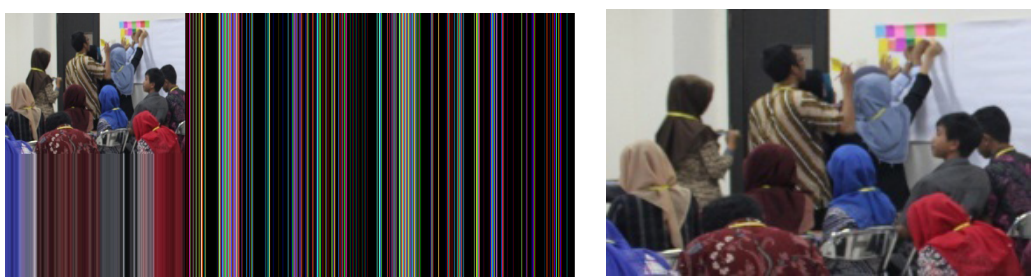

Gambar 1. Penempelan emoticon membuat kelas tidak kondusif

kelompok VI, yaitu Putri Rara Terlihat melamun dan hanya melihat temannya saja dalam proses diskusi.
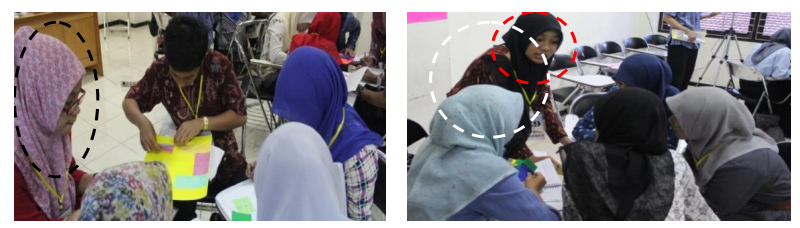

Gambar 2. Sebagian peserta kelompok yang berpartisipasi aktif dalam diskusi

Dalam proses permainan guess and check terlihat beberapa kelompok yang antusias mengikuti permainan dalam kelompoknya, seperti pada kelompok $\mathrm{V}$ mereka menyenangi permainan tersebut. Tetapi ada juga kelompok yang kebingungan dengan permainan tersebut, seperti kelompok IV dan II yang terlihat melihat proses permainan berlangsung kelompok lain.
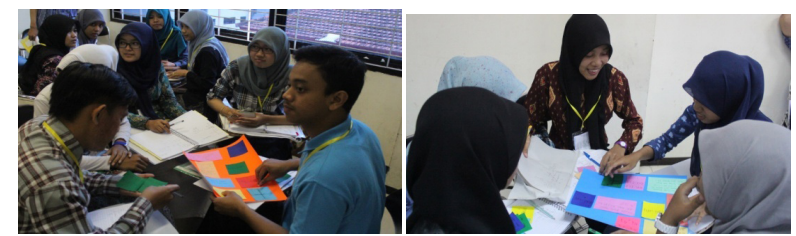

Gambar 3. Mahasiswa senang dalam permainan dan mahasiswa yang kebingungan selama proses permainan

See

Secara keseluruhan partisipasi aktif mahasiswa telah baik, hanya saja terdapat beberaapa mahasiswa yang masih membutuhkan perhatian yang lebih. Penjelasan secara rinci dalam setiap indikatornya yaitu sebagai berikut.

Partisipasi Aktif Mahasiswa :

1) Turut aktif dalam proses pembelajaran.

Hampir seluruh kelompok aktif dalam pembelajaran dan diskusi. Hal ini diindikasikan dari mahasiswa sangat aktif ketika diskusi baik dalam kelompok maupun diskusi kelas. Akan tetapi, dalam proses diskusi hanya diam dan hanya melihat proses diskusi kelompoknya saja. Apabila ditinjau dari hasil angket mahasiswa, untuk indikator ini dalam kriteria baik.

2) Mengikuti pelajaran dengan baik

Hampir seluruh mahasiswa terlihat aktif, mencatat hasil diskusi, dan mengikuti perkuliahan dengan baik. Hasil angket mahasiswa menunjukkan indikator ini berkriteria baik.
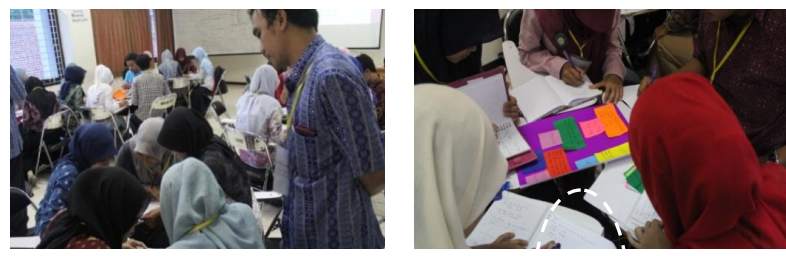

Gambar 4. Mahasiswa mengikuti perkuliahan dengan baik

3) Mengerjakan tugas baik terstruktur maupun tanpa terstruktur di kelas dan di rumah dengan baik

Mahasiswa mampu mengerjakan tugas di kelas maupun di rumah dengan baik. Sebagai contohnya Arum dapat mengerjakan tugas dengan sebaik-baiknya, hal ini terlihat dia rajin dalam mengerjakan tugas di kelas. Akan tetapi ada mahasiswa yang mengerjakan tugas di kelas dengan tidak rapi, terlihat dari hasil menggambar

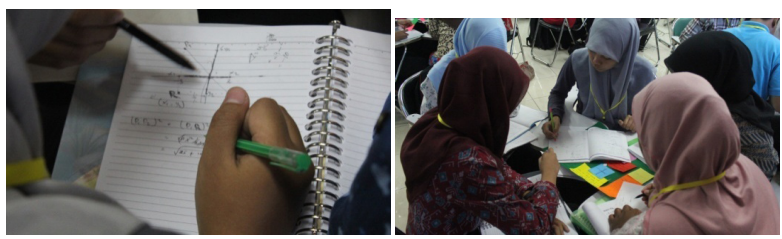

Gambar 5. Mahasiswa dapat mengerjakan tugas kelompok maupun tugas individu dengan baik 
grafik tanpa menggunakan penggaris. Hasil angket mahasiswa menunjukkan indikator ini berkriteria sangat baik.

4) Berinisiatif mempelajari dan mengerjakan materi pelajaran yang belum dan akan dikerjakan

Proses ini dilihat dari beberapa mahasiswa yang membawa sumber materi. Hasil angket mahasiswa menunjukkan untuk indikator ini berkriteria baik.

5) Menyampaikan pendapat, ide, atau sanggahan Bagi mahasiswa yang senang berbicara sangat menarik, karena mendapat kesempatan yang luas untuk mengeluarkan pendapatnya. Akan tetapi bagi mahasiswa yang pendiam hal ini idak menarik, karena mereka akan terus terdiam kecuali mendapat perintah dari dosen. Hasil angket mahasiswa menunjukkan untuk indikator ini berkriteria baik.

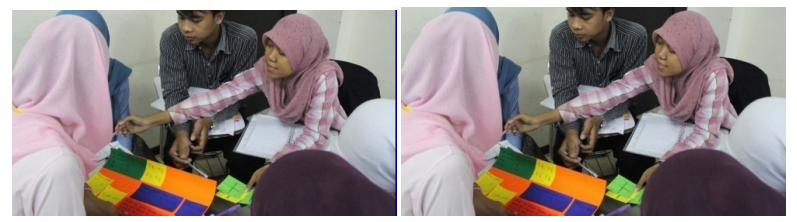

Gambar 6. Mahasiswa memberi pendapat, ide, atau sanggahan baik di proses diskusi kelompok maupun proses pembelajaran

\section{6) Mencari jalan memecahkan masalah.}

Lingkungan belajar memberikan kesempatan yang seluas-luasnya bagi mahasiswa untuk mengembangkan kemampuannya dan tidak hanya sekedar penguasaan materi pembelajaran. Mahasiswa sangat variatif dalam belajarnya, ada yang mencari pemecahan masalah dengan satu jalan adapun yang memakai pemecahan masalah dengan berbagai alternative jawaban, terlihat dari kelompok IV Dini Nur Laila dan Sukma Maharani dari kelompok III memberikan masukan
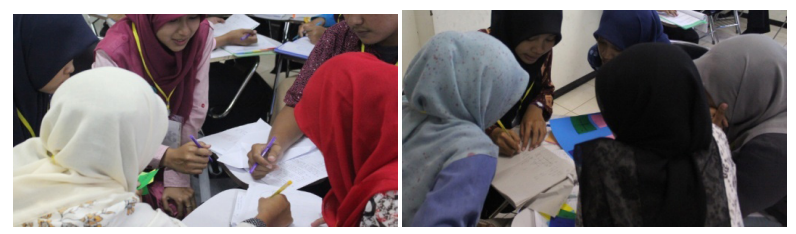

Gambar 7. Mahasiswa bersama-sama dengan kelompoknya mencari pemecahan masalah dan alternatif penyelesaian yang lain bagaimana pemecahan masalah itu terselesaikan. Hasil angket mahasiswa menunjukkan untuk indikator ini berkriteria baik.

\section{Siklus II}

Plan

Perubahan-perubahan yang dilakukan pada siklus II yaitu meliputi (1) Teknis pemasangan emoticon; (2) Posisi tempat duduk; (3) Jenis permainan (games) yaitu paper plane; (4) Mahasiswa yang membutuhkan perhatian yaitu Putri Rara (Kelompok VI), Dwi Okta (Kelompok VII), dan Danu Eka (Kelompok VIII).

\section{Do}

Posisi tempat duduk pada pembelajaran kali ini sesuai dengan yang direncanakan, yaitu saling berhadapan di sisi kanan dan sisi kiri Dosen masing-masing 5 kelompok pada setiap sisinya.

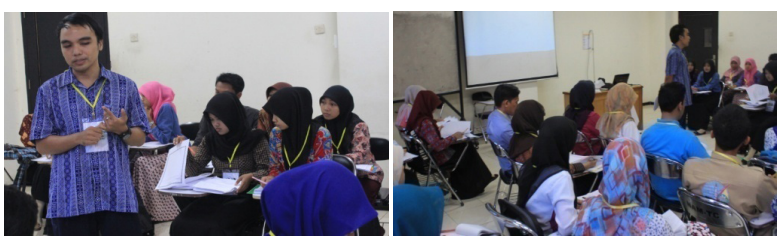

Gambar 8. Posisi tempat duduk saling berhadapan antar kelompok

Mahasiswa yang membutuhkan perhatian telah mengalami perubahan, sebagai contoh Danu Eka dan Dwi Okta telah aktif dalam diskusi, namun Putri Rara masih belum terlihat perubahannya.

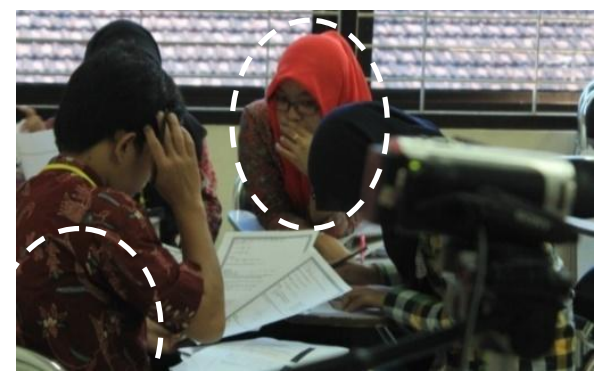

Gambar 9. Mahasiswa yang belum mengalami perubahan yait Putri Rara

Dalam proses permainannya pun, mahasiswa tampak antusias dan tertarik untuk melaksanakan permainan tersebut. Sehingga partisipasi dan 
kemandirian belajar mahasiswa meningkat dibandingkan pembelajaran sebelumnya (Do 1).
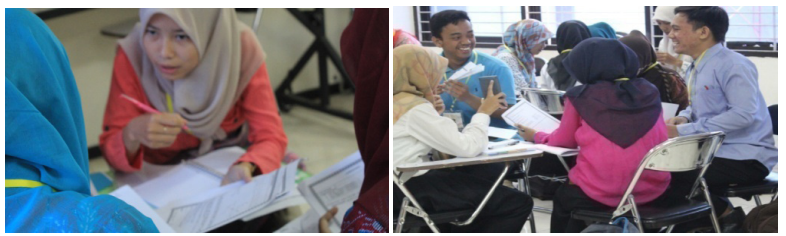

Gambar 10. Partisipasi aktif mahasiswa

lebih meningkat, dan mahasiswa tampak senang dalam permainan sehingga membuat pembelajaran lebih baik

\section{See}

Partisipasi dan kemandirian belajar mahasiswa pada siklus ini dapat dikatakan lebih baik dari siklus pertama. Penjelasan secara rinci dalam setiap indikatornya yaitu sebagai berikut.

Partisipasi Aktif Mahasiswa:

Turut aktif dalam proses pembelajaran.

Hampir seluruh kelompok aktif dalam pembelajaran dan diskusi. Hal ini diindikasikan dari mahasiswa sangat aktif ketika diskusi baik dalam kelompok maupun diskusi kelas. Hasil angket mahasiswa, untuk indikator ini dalam kriteria baik.

Mengikuti pelajaran dengan baik

Hampir seluruh mahasiswa terlihat mengikuti perkuliahan dan permainan dengan baik. Hasil angket mahasiswa menunjukkan indikator ini berkriteria baik.

Mengerjakan tugas baik terstruktur maupun tanpa terstruktur di kelas dan di rumah dengan baik

Hampir seluruh mahasiswa mampu mengerjakan tugas di kelas maupun di rumah dengan baik. Sebagai contohnya Arum dapat mengerjakan tugas dengan sebaik-baiknya, hal

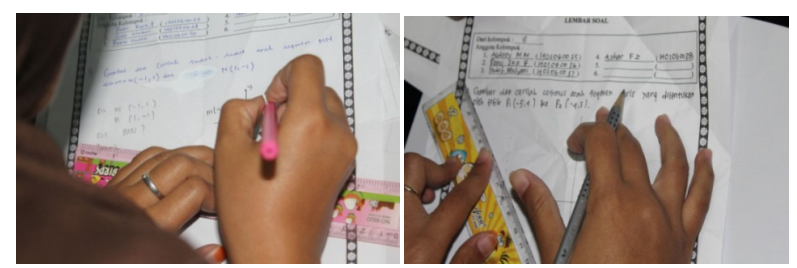

Gambar 11. Mahasiswa tidak antusias dan mengantuk saat diskusi maupun presentasi ini terlihat dia rajin dalam mengerjakan tugas di kelas. Mahasiswa sekarang sudah mulai merubah kebiasaan lama, yaitu menggambar dengan menggunakan penggaris. Hasil angket mahasiswa menunjukkan indikator ini berkriteria sangat baik.

Berinisiatif mempelajari dan mengerjakan materi pelajaran yang belum dan akan dikerjakan

Proses ini dilihat dari beberapa mahasiswa yang membawa sumber materi. Hasil angket mahasiswa menunjukkan untuk indikator ini berkriteria baik.

Menyampaikan pendapat, ide, atau sanggahan

Mahasiswa sekarang sudah mulai berani mengungkapkan pendapat, ide, atau sanggahannya di depan kelas, maupun di dalam kelompoknya. Hasil angket mahasiswa menunjukkan untuk indikator ini berkriteria baik.

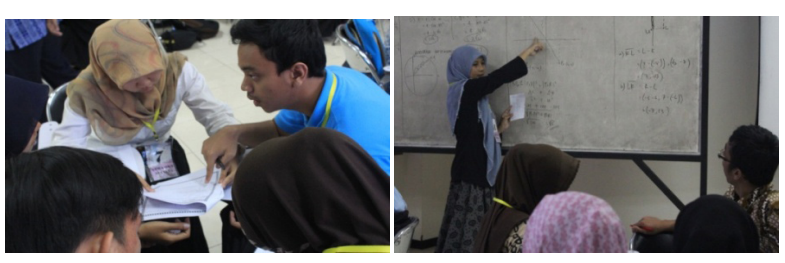

Gambar 12. Mahasiswa memberi pendapat, ide, atau sanggahan baik di proses diskusi kelompok maupun proses pembelajaran

Mencari jalan memecahkan masalah.

Proses mencari jalan memecahkan masalah dilakukan dengan proses diskusi di dalam kelompoknya, maupun proses secara mandiri yang dibantu dengan sumber belajar yang ada. Keterampilan ini mengindikasikan bahwa kemandirian dalam belajar dan partisipasi aktif mahasiswa dalam proses diskusi sudah dapat berjalan dengan baik. Hasil angket mahasiswa menunjukkan untuk indikator ini berkriteria baik.

Sedangkan indikator kemampuan komunikasi matematis tertulis sebagai berikut:

Mengekspresikan ide-ide matematis melalui tulisan, dan mendemonstrasikannya serta menggambarkannya secara visual

Untuk menghitung sebuah panjang segmen, dapat dilakukan dengan mengoperasikan beberapa sejumlah titik pada segmen tersebut. Apa yang dilakukan oleh Istiana Indri Nurvitroh dapat 
mengilustrasikan kemampuan komunikasi matematis berikut.

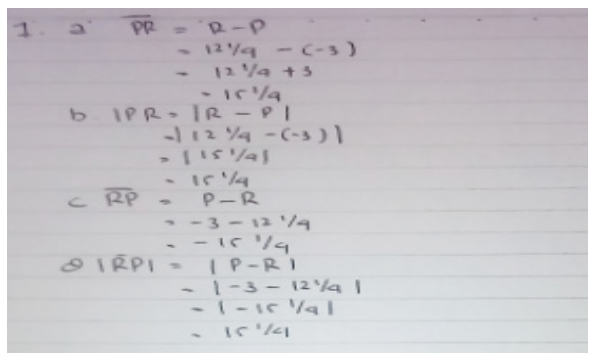

Gambar 13. Hasil pekerjaan Istiana Indri Nurvitroh tentang mencari panjang segmen

Memahami menginterpretasikan, dan mengevaluasi ide-ide matematis secara tertulis.

Ide-ide matematis seperti mencari koordinat kutub dari koordinat kartesius dapat dilakukan dengan beberapa tahapan dan mengevaluasi semua tahapan tersebut secara benar, kemampuan ini dapat dilihat dari hasil pekerjaan Ilham Kurniawan berikut.

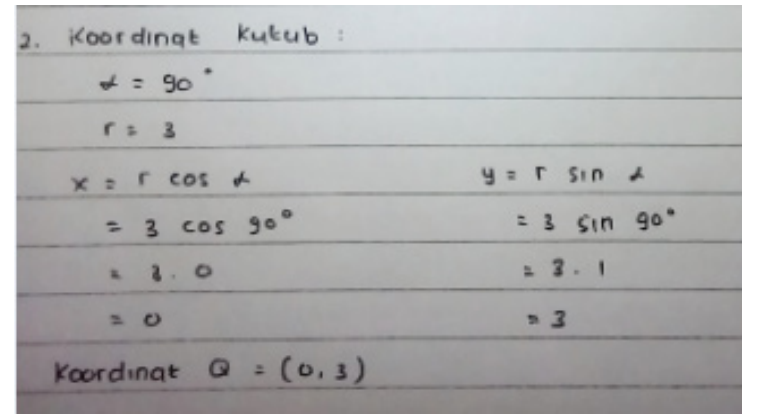

Gambar 14. Mengintepretasikan ide matematis seperti pekerjaan Ilham Kurniawan

Menggunakan istilah-istilah, notasi-notasi matematika dan struktur-strukturnya untuk menyajikan ide-ide menggambarkan hubunganhubungan dengan model-model situasi

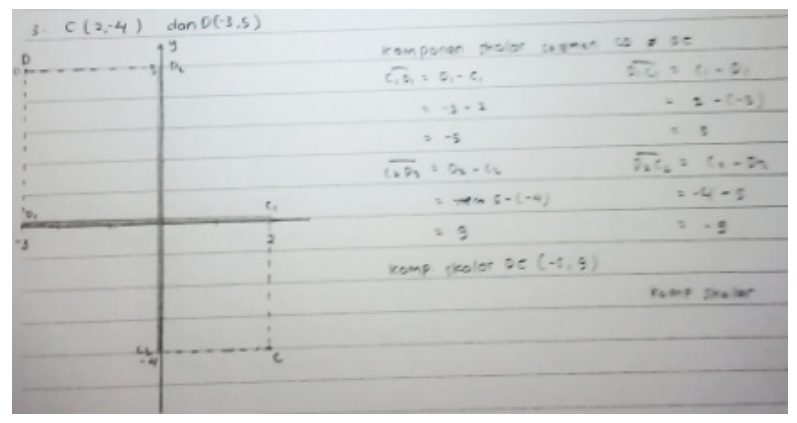

Gambar 15. Menyajikan hasil pekerjaan dengan grafik maupun dengan notasi matematika
Seperti yang dilakukan oleh Gita Islamul Khayati, dia merumuskan panjang segmen dengan menggunakan simbol maupun dengan menggunakan bentuk grafik.

\section{Siklus III \\ Plan}

Perubahan pada siklus ini yaitu bentuk permainannya yaitu Secret Inside Baloon.

\section{Do}

Pembelajaran kali ini, masalah yang baru datang dari mahasiswa yang tadinya aktif menjadi tidak semangat dalam mengikuti perkuliahan hari ini, yaitu Sukma Maharani dalam proses memperhatikan masalah pada diskusi kelompok.

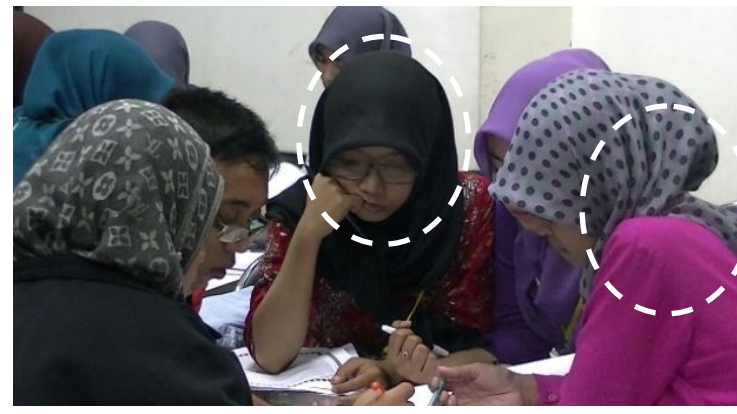

Gambar 16. Mahasiswa dengan tatapan kurang semangat dan murung

Pelaksanaan perkuliahan kali ini, selaku Dosen Model lebih banyak melakukan bimbingan kelompok (scaffolding) dikarenakan materi pembelajaran kali ini cukup banyak dan membuat mahasiswa kesulitan dalam proses diskusi.
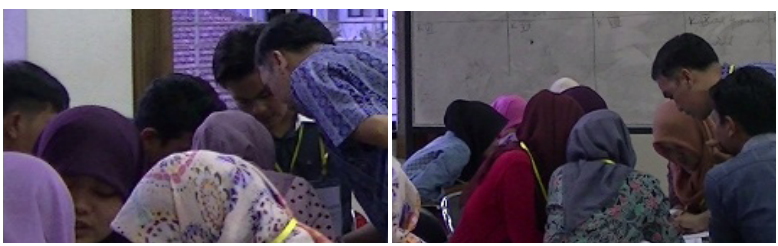

Gambar 17. Pemberian scaffolding kepada mahasiswa

See

Semua indikator pada partisipasi aktif telah terlaksana dengan baik. Semangat mahasiswa untuk berpendapat telah muncul. Satu mahasiswa yang tidak konsentrasi yaitu Indah kemungkinan besar dikarenakan kurang dalam kondisi badan 
yang tidak sehat. Hal ini terlihat pada proses pembelajaran dia Nampak murung dan bersedih. Permainan pada pembelajaran kali ini juga dapat berjalan dengan baik dan mahasiswa begitu antusias dan senang untuk melakukannya.
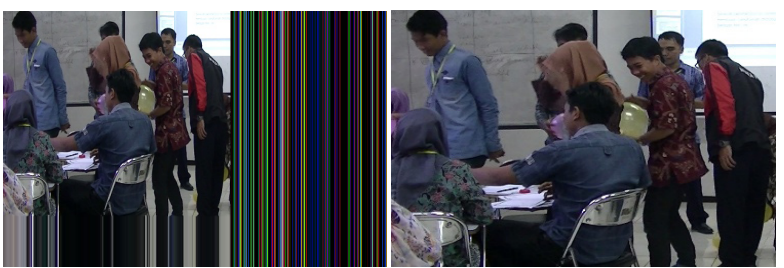

Gambar 18. Mahasiswa semangat untuk mengikuti permainan (games): Secret Inside Baloon

Sedangkan indikator kemampuan komunikasi matematis tertulis sebagai berikut:

Mengekspresikan ide-ide matematis melalui tulisan, dan mendemonstrasikannya serta menggambarkannya secara visual

Sebagai contoh, untuk mencari penjumlahan vektor dapat digunakan cara operasi penjumlahan maupun menggunakan gambar secara visual. Seperti contoh pekerjaan Indah Tri Septiyani berikut.

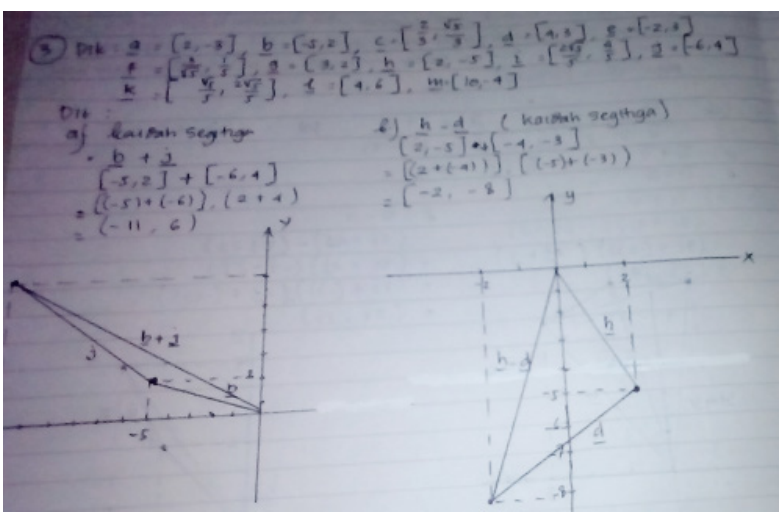

Gambar 19. Mahasiswa mengekspresikan ide matematis melalui tulisan maupun gambar visual

Memahami menginterpretasikan, dan mengevaluasi ide-ide matematis secara tertulis.

Untuk memahami suatu masalah dapat digunakan beberapa penjelasan secara logika berpikir mahasiswa, sebagai contoh terdapat soal mengenai sebuah penalaran dua segmen apakah memiliki sudut yang sama. Penjelasan salah satu mahasiswa bernama Nur Azizah menjelaskannya seperti gambar ini

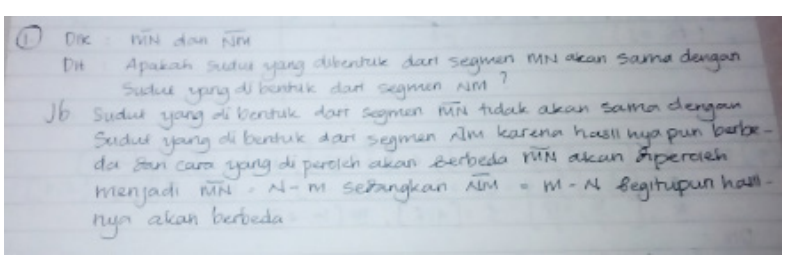

Gambar 20. Mahasiswa menginterpretasikan ide secara tertulis

Menggunakan istilah-istilah, notasi-notasi matematika dan struktur-strukturnya untuk menyajikan ide-ide menggambarkan hubunganhubungan dengan model-model situasi

Salah satu kemampuan yang terlihat adalah ketika mahasiswa diminta untuk mencari sudut diantara dua vektor. Untuk mencari sudut tersebut, mahasiswa dapat menggunakan beberapa tahapan seperti terlihat dalam gambar di bawah ini

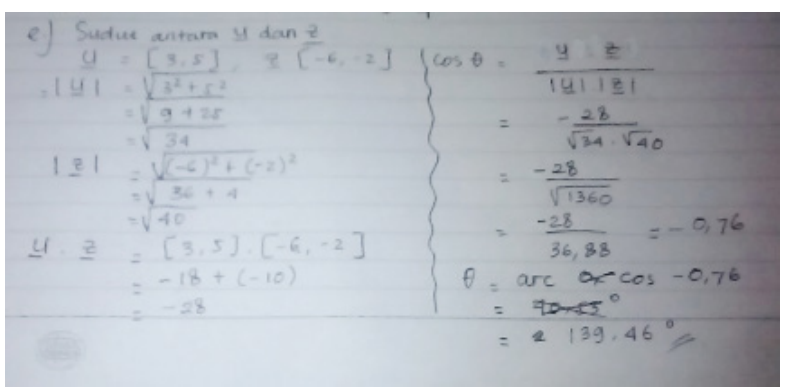

Gambar 21. Mahasiswa mengekspresikan ide matematis melalui simbol-simbol

\section{Siklus IV \\ Plan}

Pada tahap ini perkuliahan dipindahkan ke Ruang Sidang Baru FKIP, dengan asumsi luas ruangan bertambah memberikan ekspektasi mahasiswa lebih nyaman dan mobilitas mahasiswa dan observer akan lebih leluasa. Bentuk permainan pada pembelajaran kali ini adalah Mysteri Box.

Do

Kondisi ruang perkuliahan yang lebih luas memberikan dampak positif baru para mahasiswa dan para observer. Dosen Model juga lebih memiliki ruang dalam mobilitasnya memantau jalannya perkuliahan.

Mahasiswa lebih nyaman dan bersemangat untuk mengikuti perkuliahan dan Sukma Maharani semangat lagi dalam diskusi. 


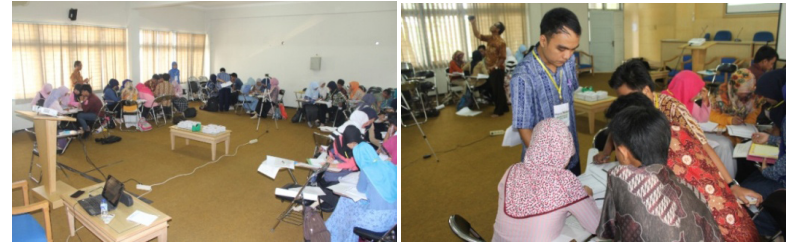

Gambar 22. Perkuliahan lebih nyaman dikarenakan kondisi ruangan lebih luas

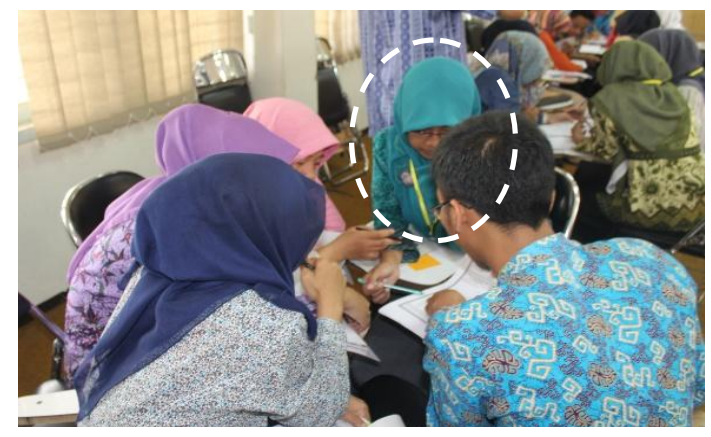

Gambar 23. Sukma Maharani telah semangat untuk berdiskusi

\section{See}

Seluruh indikator pada partisipasi aktif telah terlaksana dengan baik. Mahasiswa sangat aktif dalam mengikuti perkuliahan. Apabila ditinjau dari angket mahasiswa, terdapat sebelas pernyataan yang diberikan kepada mahasiswa berkategori sangat baik. Beberapa hal yang perlu diberikan pembenahan adalah kondisi ruang kelas, dengan luas yang memadai ternyata membuat dampak positif bagi perkuliahan.

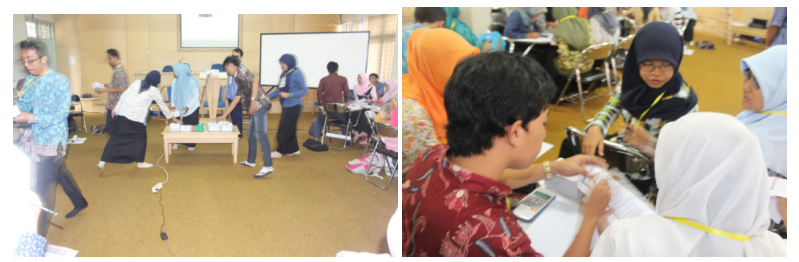

Gambar 24. Kondisi ruang kelas yang luas membuat kondisi belajar lebih nyaman bagi mahasiswa

\section{KESIMPULAN DAN SARAN}

Pembelajaran yang telah dirancang oleh dosen model dan para dosen observer telah dapat memunculkan partisipasi aktif, kemandirian belajar dan kemampuan komunikasi matematis mahasiswa. Dari hasil dan pembahasan dalam penelitian ini maka dapat disimpulkan bahwa pembelajaran pada mata kuliah Geometri Analitik Bidang yang telah dirancang melalui lesson study dapat membantu perkembangan partisipasi aktif, dan kemampuan komunikasi matematis mahasiswa. Pengembangan model pembelajaran dilakukan sesuai dengan kebutuhan pada mahasiswa.

Hasil penelitian ini memberikan saran kepada para guru dan dosen untuk memperhatikan hal-hal berikut dalam pembelajaran.

1. Perhatian dosen kepada mahasiswa harus konsisten.

2. Pengembangan model pembelajaran harus senantiasa dilakukan.

3. Sarana dan prasarana yang mendukung pembelajaran senantiasa ditingkatkan.

\section{DAFTAR PUSTAKA}

Amstrong, M.A. (2004). Instructional design in the real world: $A$ view from the trenches. Melbourne: Information Science Publishing Arends, R.I. (1997). Classroom instruction and management. New York: Mc. Graw Hill Companies

Ausubel . (1963). Meaningful verbal learning subsumption theory. London: Paul Chapman Publishing.

Bobango, T. (1993). Geometry and analytic calculus. New York : Routledge

Bistari. (2010Suparno, .(1997). Kebermaknaan dalam sebuab pembelajaran. Semarang: Cipta Karya

Isjoni. (2010). Pembelajaran Kooperatif Meningkatkan Kecerdasan Komunikasi Antar Peserta Didik. Yogyakarta: Pustaka Pelajar Johnson, D.W. \& Johnson, R.T. (2002). Meaningful assesment a manageable and cooperative process. Boston, MA: Allyn \& Bacon.

Kemendiknas, Kemenag, JICA, UPI, UNY, \& UM. (2012). Panduan Untuk Lesson Study Berbasis MGMP dan Lesson Study Berbasis Sekolah. Jakarta: IDC.

Marguerite, M. (2001). The van biele levels of geometric understanding. Boston, MA: Allyn $\&$ Bacon.

Mujiman, H. (2007). Belajar mandiri dalam lingkup pendidikan dewasa. Yogyakarta: Aneka Ilmu 
Mulyasa, .(2006). Belajar dan berpartisipasi aktif dalam pendidikan tinggi. Jakarta: Aneka Pustaka

National Council of Teacher of Mathematics (NCTM). Representation in mathematical learning and problem solving. Dalam English, Lyn D. (Eds.), Journal for research in mathematics education. (pp. 197-217). Toms River: Lawrence Erlbaum Associates, PublishersSuryosubroto. (2013). Pendidikan dan kemandirian dalam sebuab sinergi. Jakarta : Bakti Mulia Pustaka
Oh, G. \& Lim, E. (2005). The way to study and learning process. New York, NY: State University of New York.

Salma, D.P. (2007). Growing with learning process. Madison Avenue: Taylor \& Francis e-Library

Syamsuri, I., \& Ibrohim. (2012). Lesson Study. Malang: UM.

Silver, M. \& Smith, W. (1993). Comunicate into students and teachers. New York: Routledge.

Susilo, .(2009). Strategi pembelajaran matematika kontemporer. Bandung: Universitas Pendidikan Indonesia. 